\title{
SCIDiC
}

International Journal of Dentistry and Oral Science (IJDOS)

ISSN: 2377-8075

\section{Buccal Pad Of Fat - The Nature's Gift For Oral Reconstruction}

Subhashini Ramasubbu ${ }^{1 *}$, Shivangi Gaur ${ }^{1}$, Abdul Wahab $\mathrm{PU}^{2}$, Madhulaxmi Marimuthu ${ }^{2}$

${ }^{1}$ Post Graduate Student, Department of Oral and Maxillofacial Surgery, Saveetha Dental College And Hospitals, Saveetha Institute of Medical And Technical Sciences(SIMATS), Saveetha University, Chennai, India.

${ }^{2}$ Professor, Saveetha Dental College And Hospitals, Saveetha Institute of Medical And Technical Sciences(SIMATS), Saveetha University, Chennai, India.

\section{Abstract}

The buccal pad of fat was initially believed to be an anatomic structure without any function, and was even considered to be a surgical nuisance. However with time, the buccal pad of fat has been used for various intraoral reconstructions. The buccal fat pad flap (BFP) is a simple and reliable flap because of its rich blood supply and location. It needs minimal dissection and can be mobilised easily. Good rate of epithelization and low failure rate makes it more favourable for oral reconstruction. The surgical procedure is simple and has shown very good results. Buccal pad of fat can be used for various surgeries like OAF closure, OSMF, Cleft Palate, Palatal Fistula, TMJ Surgery, Closure of small defects, Biological membrane for covering bone grafts. In this study we focused the clinical application of Buccal Pad of Fat in Oral and Maxillofacial Surgery.

Keywords: Buccal Pad of Fat; Buccal Pad Fat; Oral Reconstruction.

\section{Introduction}

The buccal pad of fat is the fat tissue that is located in profound facial spaces. It lies behind zygomatic arch and it has four processes. They are buccal process, pterygoid process, the superficial process and the deep temporal process [1]. Pterygopalatie process which stays in pterygopalatine fossa was found by Chinese scientists. The volume may change throughout life.

The average weight of each buccal fat pad was found to be $9.3 \mathrm{~g}$, and its average volume was $9.6 \mathrm{ml}[2,3]$. They stated that it serves to line the masticatory space, separating the masticatory muscles from each other and from the mandibular ramus and the zygoma. This volume could be used to repair a defect measuring $4 \mathrm{x} 4 \mathrm{x}$ $3 \mathrm{~cm}$ in Maxilla \& $7 \times 5 \times 2 \mathrm{~cm}$. in mandible. Buccal pad of fat chiefly owes its blood supply primarily to the small venules and arterioles situated in the base, therefore both excessive manipulation at the base and the rupture of surrounding vascular capsule results in free fat transfer rather than vascular grafting.
Buccal Pad Of Fat is used in various Maxillofacial Surgeries [4]. It has physiological functions which include filling deep tissue space, and acts like a cushion for some structures from outer forces. It also serves as a versatile flap in some reconstructive procedures.

The application of buccal pad of fat has increased rapidly in recent years. It has been used in different kinds of surgeries. Now the scientists have been working on regenerative properties of buccal pad of fat [5].

With a rich case bank established over 3 decades we have been able to publish extensively in our domain [6-16]. Based on this inspiration we aim to present the following case series to highlight the excellent properties of buccal pad of fat as a scaffold and autogenous dressing in healing of intraoral defects like Oroantral Fistula, after excision of a lesion in oral cavity, in the treatment of OSMF and in Cleft Palate surgery.

*Corresponding Author:
Dr. Subhashini Ramasubbu,

Post Graduate Student, Department of Oral and Maxillofacial Surgery, Saveetha Dental College And Hospitals, Saveetha Institute of Medical And Technical Sciences (SIMATS), Saveetha University, Chennai, India.

Tel: 9999286618

E-mail: meetsubha07@gmail.com

Received: July 29, 2020

Accepted: September 11, 2020

Published: September 30, 2020

Citation: Subhashini Ramasubbu, Shivangi Gaur, Abdul Wahab PU, Madhulaxmi Marimuthu. Buccal Pad Of Fat- The Nature’s Gift For Oral Reconstruction. Int J Dentistry Oral Sci. 2020;7(9):824-827. doi: http://dx.doi.org/10.19070/2377-8075-20000162

Copyright: Subhashini Ramasubbu 2020 . This is an open-access article distributed under the terms of the Creative Commons Attribution License, which permits unrestricted use, distribution and reproduction in any medium, provided the original author and source are credited. 


\section{Anatomy}

Buccal pad of fat protrudes at the anterior border of the masseter muscle and extends to the parotid duct, where it rests on the buccopharyngeal fascia, which covers the buccinator muscle [1]. The main body is positioned along the posterior maxilla and it is covered with a thin capsule. The parotid duct pierces the buccinator at the anterior border of the buccal fat pad. The buccal fat pad has abundant blood supplies from the maxillary artery and the superficial and deep temporal artery. There are rich capillary networks within the capsules that cover the fat pad. Arterioles enter the capsule from several directions and break up into capillary plexuses. Most of the blood from the fat pad drains into the facial vein $[17]$.

\section{Case 1}

\section{Closure Of Oroantral Fistula}

A 35 year old male patient came to the Department of Oral and Maxillofacial Surgery with a chief complaint of Right hemifacial pain and discharge from non healed orifice after extraction of right upper third molar 6 months before. On examination, there was a $5-6 \mathrm{~mm}$ fistula which communicates the left maxillary sinus. No pus or inflammation seen. Diagnosis was made as oroantral Fistula. The treatment plan was to close the fistula using a buccal pad of fat. Vestibular incision was given in relation to the right upper first molar till third molar region. Full thickness muco periosteal flap elevated and Fistula was noted. Buccal pad of fat was harvested (Figure 1) and it was used to close the fistula. Simple interrupted sutures were placed to secure the fat pad.

Figure 1.

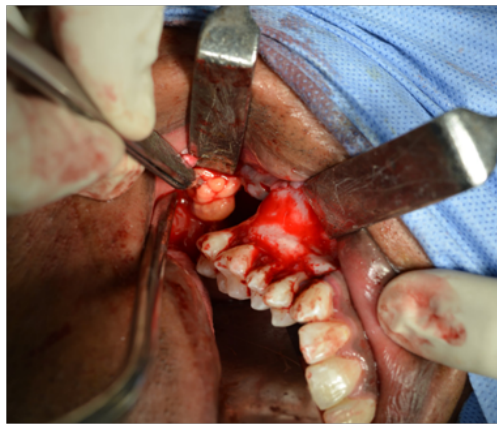

Case 2

\section{Cleft Palate Surgery}

A 10 months old baby presented with Cleft Palate to the Department of Oral and Maxillofacial Surgery for the primary repair. Using Bardach's technique, primary palatoplasty was done. Buccal pad of fat can be used as a packing material to cover the raw bone (Figure 2). Using blunt dissection, a buccal pad of fat was harvested and then placed toward the area of the defect and sutured with light pressure to the edge of the flap and left open for the epithelialization. Satisfactory healing was noted postoperatively.
Figure 2.

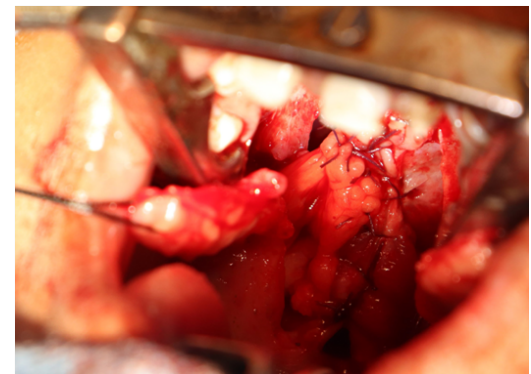

\section{Case 3}

\section{Surgical Management Of Oral Submucous Fibrosis Using Buccal Pad Of Fat}

Different surgical procedures described in the literature claim different success rates. The use of a Buccal pad of fat as a grafting material is relatively good. The fibrous bands were detected by digital palpation. Horizontal incision given along the occlusal plane in buccal mucosa. Incision extends anteriorly from the corner of the mouth till pterygomandibular raphe posteriorly. Using fingers, bands were released. The mouth was then forced to open with the mouth gag to an acceptable range of approximately $40 \mathrm{~mm}$. A small amount of the lesions were excised and sent for biopsy. The buccal pad of fat was harvested from the defect, that is posterior to zygomatic buttress. After blunt dissection, buccal pad of fat was gently mobilised until the required amount was obtained to cover the defect. It should be covered without tension (Figure 3). This can be done by gently pulling it using small artery forceps. This pedicled fat pad was used to cover the areas. And secured by placing horizontal mattress sutures using 3-0 Vicryl.

Figure 3.

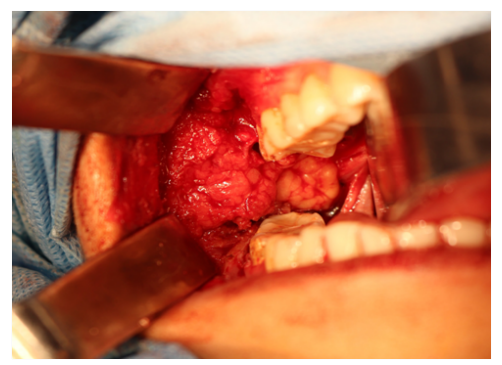

Case 4

\section{Closure Of Defect Using Buccal Pad Of Fat After Excision Of Lesion}

A 29 year old female patient reported to the Department of Oral and Maxillofacial Surgery with a history of painless gradually progressive swelling in the right side of the face for the past 3 years. It was slow growing, no pain associated with it. On examination it was diffuse, non-tender, bony hard swelling of approximately $5 \times 6 \mathrm{~cm}$ extending from upper right canine till right upper molar. Under general anesthesia, excision of the lesion done and sent for histopathological examination. Buccal pad of fat was harvested and used to cover the defect (Figure 4,5). 
Figure 4.

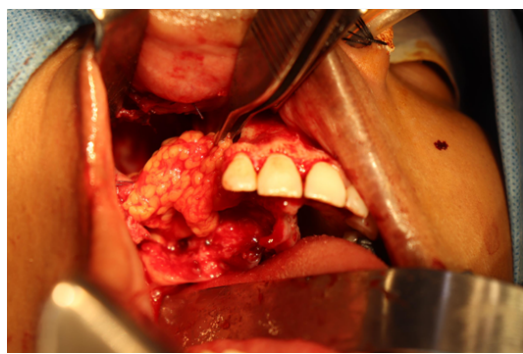

Figure 5.

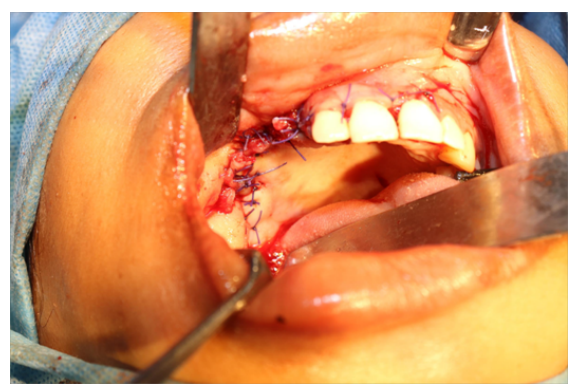

\section{Discussion}

The anatomy of the buccal pad of fat is complex. A detailed review of anatomy was described by [18]. It has a main body and four processes. The main body lies above the parotid duct on the anterior border of the masseter muscle and extends deeply to lie on the posterior maxilla and forward along the buccal vestibule. The buccal extension is superficial and enters the cheek below the parotid duct. It descends to the mandibular retromolar region and overlies the buccinator muscle.

The pterygoid extension of the fat pad passes down and back to lie on the lateral surfaces of the pterygoid plates. Its temporal extension passes upwards below the zygomatic arch, and comprises a deep and a superficial portion. The deep part lies directly on the temporalis muscle and its tendon, separating the temporalis muscle from the zygomatic arch. The blood supply of the BFP is from three sources: the maxillary artery (buccal and deep temporal branches), the superficial temporal artery (transverse facial branch), and the facial artery (small branches). Once the fascial envelope of the BFP is opened, spontaneous fat pad herniation into the mouth occurs $[2,18]$.

[19] was the first surgeon to report the use of the buccal fat pad as a pedicled graft for the closure of oro-antral and oronasal communications: a split-thickness skin graft was used to line the oral side of the fat pad $[19,20]$. reported the use of the buccal fat pad as a free graft for reconstruction of defects within the oral cavity [18]. have shown that the buccal fat pad need not be covered by a skin graft when brought into the mouth because of its quick epithelization within 3 weeks. They have reported that the superficial layer of fat tissue is replaced by granulation tissue and is finally covered by stratified squamous epithelium.

[21] reported successful results with the use of the BFP in reconstruction of both palatal and cheek defects. It can also be used in medicine related osteoradionecrosis of the jaws (MRONJ) re- ported by [21, 22]. [23] successfully reported the use of buccal pad of fat in oroantral communication [24]. reported that the buccal pad of fat was not affected by postoperative radiation therapy in cancer patients.

[25] reported that this flap has significant potential to function as an added vascularized tissue layer in cleft palate repair. Advantages of using buccal pad of fat include it provides vascular coverage to the denuded bone, it lacks scarring effect, serves as a bed for secondary granulation, it obliterates dead space at the alveolar defect.

[26-28] and various other authors reported the use of buccal pad of fat in the treatment of OSMF [29-31]. reported that buccal pad of fat provided better results compared to naso labial flap in the treatment of OSMF.

\section{Conclusion}

From this study, We conclude that the buccal pad of fat is rapidly healing, less invasive, easy to harvest \& manipulate and also acts as a reconstructive material which is free from significant postoperative complications.

\section{References}

[1]. Tostevin PM, Ellis H. The buccal pad of fat: a review. Clin Anat. 1995;8(6):403-6. Pubmed PMID: 8713160.

[2]. Kumar R. Buccal fat pad graft in oral and maxillofacial surgery-A review. Asian Pacific Journal of Health Sciences. 2018 Dec 30;5(4):1-0

[3]. Arce K. Buccal Fat Pad in Maxillary Reconstruction [Internet]. Atlas of the Oral and Maxillofacial Surgery Clinics. 2007;15: 23-32. Available from: http://dx.doi.org/10.1016/j.cxom.2006.11.003

[4]. Yousuf S, Tubbs RS, Wartmann CT, Kapos T, Cohen-Gadol AA, Loukas M. A review of the gross anatomy, functions, pathology, and clinical uses of the buccal fat pad. SurgRadiol Anat. 2010 Jun;32(5):427-36.PubmedPMID: 19937328.

[5]. Salehi-Nik N, Rezai Rad M, Kheiri L, Nazeman P, Nadimi N, Khojasteh A. Buccal Fat Pad as a Potential Source of Stem Cells for Bone Regeneration: A Literature Review. Stem Cells Int. 2017 Jul 5;2017:8354640.PubmedPMID: 28757880.

[6]. Senthil Kumar MS, Ramani P, Rajendran V, Lakshminarayanan P. Inflammatory pseudotumour of the maxillary sinus: clinicopathological report. Oral Surg. 2019 Aug 10;12(3):255-9.

[7]. Wahab PUA, Madhulaxmi M, Senthilnathan P, Muthusekhar MR, Vohra Y, Abhinav RP. Scalpel Versus Diathermy in Wound Healing After Mucosal Incisions: A Split-Mouth Study. J Oral Maxillofac Surg. 2018 Jun;76(6):11604.PubmedPMID: 29406253.

[8]. J PC, Marimuthu T, C K, Devadoss P, Kumar SM. Prevalence and measurement of anterior loop of the mandibular canal using CBCT: A cross sectional study. Clin Implant Dent Relat Res. 2018 Aug;20(4):531-4.Pubmed PMID: 29624863.

[9]. Eapen BV, Baig MF, Avinash S. An Assessment of the Incidence of Prolonged Postoperative Bleeding After Dental Extraction Among Patients on Uninterrupted Low Dose Aspirin Therapy and to Evaluate the Need to Stop Such Medication Prior to Dental Extractions. J Maxillofac Oral Surg. 2017 Mar;16(1):48-52.PubmedPMID: 28286384.

[10]. Marimuthu M, Andiappan M, Wahab A, Muthusekhar MR, Balakrishnan A, Shanmugam S. Canonical Wnt pathway gene expression and their clinical correlation in oral squamous cell carcinoma. Indian J Dent Res. 2018 May;29(3):291-7.PubmedPMID: 29900911.

[11]. Jain M, Nazar N. Comparative Evaluation of the Efficacy of Intraligamentary and Supraperiosteal Injections in the Extraction of Maxillary Teeth: A Randomized Controlled Clinical Trial. J Contemp Dent Pract. 2018 Sep;19(9):1117-21.PubmedPMID: 30287714.

[12]. Abhinav RP, Selvarasu K, Maheswari GU, Taltia AA. The Patterns and Etiology of Maxillofacial Trauma in South India. Ann Maxillofac Surg. 2019 Jan;9(1):114-7.PubmedPMID: 31293938.

[13]. Sweta VR, Abhinav RP, Ramesh A. Role of Virtual Reality in Pain Perception of Patients Following the Administration of Local Anesthesia. Ann Maxil- 
lofac Surg. 2019 Jan;9(1):110-3. Pubmed PMID: 31293937.

[14]. Abdul Wahab PU, Senthil Nathan P, Madhulaxmi M, Muthusekhar MR, Loong SC, Abhinav RP. Risk Factors for Post-operative Infection Following Single Piece Osteotomy. J Maxillofac Oral Surg. 2017 Sep;16(3):328-32. Pubmed PMID: 28717291

[15]. Ramadorai A, Ravi P, Narayanan V. RhinocerebralMucormycosis: A Prospective Analysis of an Effective Treatment Protocol. Ann Maxillofac Surg. 2019 Jan;9(1):192-6.PubmedPMID: 31293952.

[16]. Patil SB, Durairaj D, Suresh Kumar G, Karthikeyan D, Pradeep D. Comparison of Extended Nasolabial Flap VersusBuccal Fat Pad Graft in the Surgical Management of Oral Submucous Fibrosis: A Prospective Pilot Study. J Maxillofac Oral Surg. 2017 Sep;16(3):312-21.Pubmed PMID: 28717289.

[17]. Kim M-K, Han W, Kim S-G. The use of the buccal fat pad flap for oral reconstruction [Internet]. Maxillofacial Plastic and Reconstructive Surgery. 2017;39. Available from: http://dx.doi.org/10.1186/s40902-017-0105-5

[18]. Tideman H, Bosanquet A, Scott J. Use of the buccal fat pad as a pedicled graft. J Oral Maxillofac Surg. 1986 Jun;44(6):435-40.PubmedPMID: 3457926.

[19]. Egyedi P. Utilization of the buccal fat pad for closure of oro-antral and/or oro-nasal communications. J Maxillofac Surg. 1977 Nov;5(4):241-4. PubmedPMID: 338848.

[20]. Neder A. Use of buccal fat pad for grafts. Oral Surg Oral Med Oral Pathol. 1983 Apr; 55(4):349-50. Pubmed PMID: 6574411.

[21]. Stuzin JM, Wagstrom L, Kawamoto HK, Baker TJ, Anthony Wolfe S. The Anatomy and Clinical Applications of the Buccal Fat Pad [Internet]. Plastic and Reconstructive Surgery. 1990; 85: 29-37. Available from: http://dx.doi. org/10.1097/00006534-199001000-00006

[22]. Rotaru H, Kim M-K, Kim S-G, Park Y-W. Pedicled Buccal Fat Pad Flap as a Reliable Surgical Strategy for the Treatment of Medication-Related Osteonecrosis of the Jaw [Internet]. Journal of Oral and Maxillofacial Surgery. 2015;73: 437-42. Available from: http://dx.doi.org/10.1016/j. joms.2014.09.023

[23]. De Biasi M, Maglione M, Angerame D. The effectiveness of surgical management of oroantral communications: a systematic review of the literature. Eur J Oral Implantol. 2014 Winter;7(4):347-57.PubmedPMID: 25422823.
[24]. Kim Y-K, Yun P-Y, Oh J-S, Kim S-G. Prognosis of closure of large sinus membrane perforations using pedicledbuccal fat pads and a resorbable collagen membrane: case series study. J Korean Assoc Oral Maxillofac Surg. 2014 Aug;40(4):188-94.Pubmed PMID: 25247149.

[25]. Ladani P, Sailer H. Application of buccal fat pad for lining of lateral defect in cleft palate repair and review of literature [Internet]. Journal of Cleft Lip Palate and Craniofacial Anomalies. 2016;3: 63. Available from: http://dx.doi. org/10.4103/2348-2125.187507

[26]. Mehrotra D, Pradhan R, Gupta S. Retrospective comparison of surgical treatment modalities in 100 patients with oral submucous fibrosis [Internet]. Oral Surgery, Oral Medicine, Oral Pathology, Oral Radiology, and Endodontology. 2009;107: e1-10. Available from: http://dx.doi.org/10.1016/j. tripleo.2008.12.012

[27]. Saravanan K, Narayanan V. The use of buccal fat pad in the treatment of oral submucous fibrosis: a newer method. Int J Dent. 2012 May 15;2012:935135. PubmedPMID: 22666254.

[28]. Ebenezer V, Balakrishnan B, Prakash D, Julius A. Versatality of Buccal Pad Fat Grafts in Surgical Treatment of Oral Submucous Fibrosis [Internet]. Biosciences Biotechnology Research Asia. 2013;10: 465-9. Available from: http://dx.doi.org/10.13005/bbra/1154

[29]. Vadepally AK. "A Comparative Clinical Evaluation of the Buccal Fat Pad and Extended Nasolabial Flap in the Reconstruction of the Surgical Defect in Oral Submucous Fibrosis Patients": A Commentary [Internet]. Journal of Oral and Maxillofacial Surgery. 2018;76:1833.

[30]. Agrawal D, Pathak R, Newaskar V, Idrees F, Waskle R. A Comparative Clinical Evaluation of the Buccal Fat Pad and Extended Nasolabial Flap in the Reconstruction of the Surgical Defect in Oral Submucous Fibrosis Patients [Internet]. Journal of Oral and Maxillofacial Surgery. 2018;76: 676.e1-676. e5. Available from: http://dx.doi.org/10.1016/j.joms.2017.11.013

[31]. Pardeshi P, Padhye M, Mandlik G, Mehta P, Vij K, Madiwale G, et al. Clinical evaluation of nasolabial flap \& buccal fat pad graft for surgical treatment of oral submucous fibrosis - a randomized clinical trial on 50 patients in Indian population [Internet]. International Journal of Oral and Maxillofacial Surgery. 2015;44: e121-2. Available from: http://dx.doi.org/10.1016/j. ijom.2015.08.733 